\title{
Patients with paroxysmal nocturnal hemoglobinuria have a high frequency of peripheral-blood T cells expressing activating isoforms of inhibiting superfamily receptors
}

\author{
Alessandro Poggi, Simone Negrini, Maria Raffaella Zocchi, Anna-Maria Massaro, Lucia Garbarino, Sonia Lastraioli, Lucia Gargiulo, \\ Lucio Luzzatto, and Rosario Notaro
}

\begin{abstract}
Patients with paroxysmal nocturnal hemoglobinuria (PNH) have a large clonal population of blood cells deriving from hematopoietic stem cells (HSCs) deficient in glycosylphosphatidylinositol (GPI)anchored surface molecules. A current model postulates that $\mathrm{PNH}$ arises through negative selection against normal HSCs exerted by autoreactive T cells, whereas PNH HSCs escape damage. We have investigated the inhibitory receptor superfamily (IRS) system in 13 patients with PNH. We found a slight increase in the
\end{abstract}

proportion of $\mathrm{T}$ cells expressing IRS. In contrast to what applies to healthy donors, the engagement of IRS molecules on T cells from patients with PNH elicited a powerful cytolytic activity in a redirected killing assay, indicating that these IRSs belong to the activating type. This was confirmed by clonal analysis: $50 \%$ of IRS $^{+}$T-cell clones in patients with $\mathbf{P N H}$ were of the activating type, while only $5 \%$ were of the activating type in healthy donors. Moreover, the ligation of IRS induces (1) production of tumor necrosis factor $\alpha$ (TNF- $\alpha$ ) and interferon $\gamma$ (IFN- $\gamma$ ) and (2) brisk cytolytic activity against cells bearing appropriate IRS counterligands. In addition, these IRS ${ }^{+} \mathbf{T}$ cells show natural killer (NK)-like cytolytic activity to which GPI- cells were less sensitive than $\mathrm{GPI}^{+}$cells. Thus, $\mathrm{T}$ cells with NK-like features, expressing the activating isoforms of IRS, may include effector cells involved in the pathogenesis of $\mathrm{PNH}$. (Blood. 2005;106:2399-2408)

() 2005 by The American Society of Hematology

\section{Introduction}

Paroxysmal nocturnal hemoglobinuria $(\mathrm{PNH})$ is a clonal disorder of the hematopoietic stem cell (HSC) ${ }^{1}$ characterized by an acquired somatic mutation in the $P I G-A$ gene $^{2,3}$; this results in a deficiency on the cell membrane of all proteins anchored by the glycosylphosphatidylinositol (GPI) molecules. ${ }^{4,5} \mathrm{PNH}$ is closely related to idiopathic aplastic anemia (IAA), ${ }^{6,7}$ which in turn is thought to result from an auto immune attack against HSCs. ${ }^{8}$ Indeed, thorough analysis of the T-cell repertoire has revealed an increased frequency of expanded T-cell clones in both $\mathrm{PNH}^{9,10}$ and IAA. ${ }^{10,11}$ This set of facts could be interpreted as suggesting that in PNH autoreactive T cells cause the selective destruction of normal HSCs, whereas HSCs with a PIG-A mutation and consequently with a $\mathrm{GPI}^{-}$ phenotype can escape T-cell-mediated damage, thus being able to survive and expand. ${ }^{12-14}$ The identity of the putative autoreactive $\mathrm{T}$ cells and of their molecular targets remain unknown.

Recent studies have identified a subset of peripheral-blood $\mathrm{T}$ lymphocytes expressing on their surface molecules that are members of the inhibitory receptor superfamily (IRS), including killer immunoglobulin (Ig)-like receptor (KIR, CD158) or C-lectin type inhibitory receptors (CLIRs, CD94/NKG2). ${ }^{15-17}$ Upon interaction with HLA-I expressed on autologous cells, these IRSs can deliver an inhibitory signal leading to the reduction of cytolytic activity as well as to the inhibition of cytokine secretion. ${ }^{18-20}$ This inhibitory

From the Laboratory of Experimental Oncology and the Laboratory of Human Genetics, National Institute for Cancer Research, the Laboratory of Clinical Immunology, Department of Internal Medicine, University of Genoa, and the Laboratory of Hystocompatibility/IBMDR, Galliera Hospital, Genoa, Italy; and the Laboratory of Tumor Immunology, San Raffaele Scientific Institute, Milan, Italy.

Submitted November 12, 2004; accepted May 30, 2005. Prepublished online as Blood First Edition Paper, June 14, 2005; DOI 10.1182/blood-2004-11-4315.

Supported in part by the Associazione Italiana Ricerca Cancro (A.P., M.R.Z., L.L., effect is mediated by the association of IRS with tyrosine phosphatases, such as Src homology 2-containing protein tyrosine phosphatase-1 (SHP-1), which in turn block the positive signal delivered by activating T-cell surface molecules. ${ }^{15-17}$ In addition to the inhibitory isoforms of IRS, activating isoforms also exist. ${ }^{15-17}$ The engagement of activating IRS leads to activation of effector-cell functions including cytolytic activity, cytokine production, and proliferation. ${ }^{15-24}$ In healthy donors, IRS $^{+} \mathrm{T}$ lymphocytes express surface markers characteristic of memory $\mathrm{T}$ cells..$^{25,26}$ Thus, it has been proposed that this T-cell subset may be expanded in the course of long-term stimulation (eg, in certain viral infections and autoimmune processes). ${ }^{27}$ Interestingly, it has been reported that $\mathrm{T}$ cells bearing activating isoforms of IRS are increased in the sinovial fluid of patients with rheumatoid arthritis, suggesting that these cells may play a role in the pathogenesis of this disease. ${ }^{24}$ Indeed, T cells bearing activating IRS may actually recognize self-major histocompatibility complex (MHC) alleles and thus activate autoimmune reaction.

We have characterized IRS ${ }^{+}$T cells in patients with $\mathrm{PNH}$, and we have found distinctive qualitative abnormalities. The engagement of IRS molecules on cells belonging to this T-cell subset induced triggering of cytolytic activity and production of cytokines. This indicates that the IRS ${ }^{+} \mathrm{T}_{-}$-cell population found in

Reprints: Alessandro Poggi, Laboratory of Experimental Oncology D, Department of Translational Oncology, National Institute for Cancer Research, Largo R. Benzi 10,16132-Genoa, Italy; e-mail: alessandro.poggi@istge.it.

The publication costs of this article were defrayed in part by page charge payment. Therefore, and solely to indicate this fact, this article is hereby marked "advertisement" in accordance with 18 U.S.C. section 1734.

C 2005 by The American Society of Hematology 


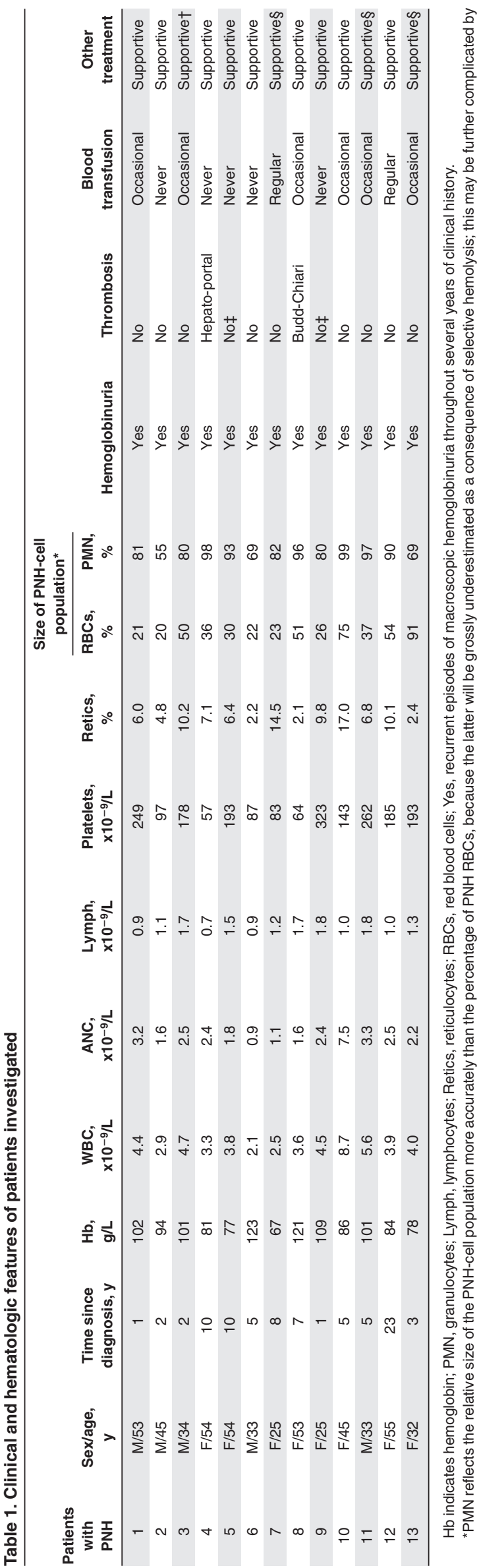

patients with $\mathrm{PNH}$, in contrast to healthy donors, tends to bear IRS of activating type, which may be involved in the pathogenesis of PNH.

\section{Patients, materials, and methods}

\section{Subjects}

Blood samples from 13 patients with hemolytic PNH (median age, 45 years; range, 24-55 years) and from 38 healthy individuals (median age, 42 years; range, 28-50 years) were collected after informed consent was obtained according to National Institute for Cancer Research (IST-Genoa) institutional procedure. We included only patients with primary classic PNH who had a large $\mathrm{PNH}$ population $\left(\mathrm{GPI}^{-}\right.$granulocytes over $40 \%$ ), florid hemoglobinuria, and no severe cytopenias (Table 1). No patient was receiving any immunosuppressive drug at the time of the study. Few patients have been studied during the follow-up with blood sampling about 3 months apart.

\section{Cell separation and analysis}

Mononuclear peripheral-blood cells (PBMCs) were isolated by density gradient centrifugation (Ficoll Hypaque; Sigma, St Louis, MO) as described $^{28}$ and used in immunofluorescence and functional assays. Absolute number of $\mathrm{CD}^{+} \mathrm{KIR}^{+}$or $\mathrm{CD}^{-} \mathrm{KIR}^{+}$or $\mathrm{CD}_{3}^{+} \mathrm{CLIR}^{+}$or $\mathrm{CD}^{-} \mathrm{CLIR}^{+}$ lymphocytes was calculated on the basis of lymphocyte counts and the percentage of each cell population determined after surface staining with the corresponding antibodies and analysis on a FACSort (Becton Dickinson, Palo Alto, CA).

\section{Monoclonal antibodies (mAbs) and reagents}

The anti-CD16 (NK54, IgG1) mAb, the anti-CD56 (TA181H12, IgG2a) $\mathrm{mAb}$, the anti-CD54 (14D12D2, IgG1) mAb, the anti-CD3 (JT3A, IgG2a) $\mathrm{mAb}$, the anti-CD8 $\alpha$ (astra102, IgG1) mAb, the pan KIR2D NKVFS1 mAb (recognizing a common epitope of CD158 a/h and of CD158b/j), and p50.3 (CD158i) were produced as described. ${ }^{15,28,29}$ The anti-CD3 (Leu4, IgG1), anti-CD4 (Leu3a, IgG1), and anti-CD8 (Leu2a, IgG1) mAbs were from Becton Dickinson. The anti-CD94 (HP-3B1, IgG2a; or E94, IgG1), anti-CD158a/h (KIR2DL1/S1) (EB6, IgG1), and anti-CD158b/j (KIR2DL2/ S2) (GL183, IgG1) mAbs were from Serotec (Kidlington, Oxford, United Kingdom). The affinity-purified goat antimouse (GAM) anti-isotype specific antiserum was from Southern Biotechnology (Birmingham, AL). Purified GAM anti-Ig $(\mathrm{H}+\mathrm{L})$ was purchased from Sigma. The EasySep Custom kit was purchased from Stemcell Biotechnologies (Vancouver, BC, Canada). Recombinant interleukin 2 (rIL2) was from Chiron (Proleukin; Chiron Italia, Siena, Italy). Cells were cultured in RPMI 1640 medium with glutamine and pennicillin-streptomycin (Biochrom, Berlin, Germany) supplemented with $10 \%$ fetal calf serum (FCS; Sigma).

\section{Indirect immunofluorescence}

Immunofluorescence staining was performed as described. ${ }^{28}$ Briefly, aliquots of $10^{5}$ cells were stained with the indicated mAbs followed by either the fluorescein isothiocyanate (FITC)- or phycoerythrin (PE)-conjugated anti-isotype-specific GAM antiserum or with an unrelated $\mathrm{mAb}$ followed by the fluorescent second reagent. Samples were analyzed on a flow cytometer (FACSort; Becton Dickinson) equipped with a 488-nm argon ion laser exciting FITC, PE, or peridinin chlorophyll (PerCP), and results are expressed as Log green (x-axis) versus red (y-axis) mean fluorescence intensity (MFI) in arbitrary units (au). In some experiments triple immunofluorescence staining was performed with anti-CD3-PerCP, anti-CD94-PE (HP-3B1), and Leu7-FITC- or CD8-FITC-conjugated mAbs. Then samples were run on a FACSort by gating either $\mathrm{CD} 3{ }^{+} \mathrm{CD} 94^{+}$or $\mathrm{CD} 3{ }^{+} \mathrm{CD} 94^{-}$cells.

\section{Generation of T-cell clones expressing IRS}

$\mathrm{CD}^{+} \mathrm{IRS}^{+} \mathrm{T}$ cells were isolated from PBMCs of patients with PNH or healthy volunteers by positive selection using anti-CD94 (E94, IgG1) mAb 
and custom preparation of EasySep (Stemcell Biotechnologies). The resulting cell population was $60 \%$ to $90 \% \mathrm{CD} 4^{+}$and $50 \%$ to $95 \% \mathrm{CD}^{+}$ depending on the donor. Purified $\mathrm{CD} 94^{+}$cells were stimulated with 10 $\mu \mathrm{g} / \mathrm{mL}$ phytohemagglutinin (PHA) and cultured in 96-well U-bottomed microplates (Becton Dickinson) with complete medium in the presence of $100 \mathrm{U} / \mathrm{mL} \mathrm{rIL} 2$ in a final volume of $200 \mu \mathrm{L} /$ well in the presence of $10^{5} /$ well irradiated allogeneic PBMCs and $5 \times 10^{3} /$ well 721.221 lymphoblastoid cell line transfected with HLA-G. ${ }^{30} \mathrm{CD}^{+}$T-cell clones were obtained by culturing purified $\mathrm{CD} 94^{+}$cells under limiting dilution conditions as previously reported..$^{29,30}$ Briefly, CD $94^{+}$cells were cultured in U-bottomed plates at different numbers of cells per well (25/well, 10/well, 5/well, $1 /$ well, and $0.5 /$ well) in the presence of $10^{5}$ irradiated PBMCs and $10^{3}$ irradiated 721.221 HLA-I-negative lymphoblastoid cell line with $1 \mu \mathrm{g} / \mathrm{mL}$ PHA and $100 \mathrm{IU} / \mathrm{mL}$ IL2. After 5 days medium was changed and cell proliferation was detected from day 10 of culture. Cloning efficiency ranged from $10 \%$ to $30 \%$, calculated as described. ${ }^{31}$ All cell populations were analyzed for the expression of CD3, CD94/NKG2, CD16, CD56, KIR2DL1/S1 with EB6 mAb, and KIR2DL2/S2 with GL183 mAb. For the expression of KIR2DS4, cells reacted with NKVFS1 mAb but not with EB6 and GL183 mAbs. Each clone was analyzed in a redirected killing assay using the $\mathrm{Fc} \gamma \mathrm{R}^{+} \mathrm{P} 815$ murine mastocytoma cell line in the presence of mAbs recognizing either KIR (anti-CD158 mAb, NKVFS1) or CLIR (anti-CD94 mAb, E94) at the effector-to-target (E/T) ratio of 20:1 or 2:1 to identify clones with inhibiting or activating forms of these HLA-I receptors, respectively. ${ }^{30}$ Indeed, when the engagement of either KIR or CLIR triggered cytolysis of $\mathrm{P} 815$ at a 2:1 E/T ratio, that clone was assigned to the activating group. On the other hand, when cytolysis of P815 at a 20:1 E/T ratio was inhibited by the addition of either anti-KIR or anti-CLIR mAb, that clone expressed IRS of the inhibiting type. ${ }^{30}$

\section{Determination of IFN- $\gamma$ and TNF- $\alpha$ in culture supernatants}

Interferon $\gamma$ (IFN- $\gamma$ ) and tumor necrosis factor $\alpha(\mathrm{TNF}-\alpha)$ released in culture supernatant from T-cell clones derived from PBMCs of patients with $\mathrm{PNH}$ upon incubation for 24 hours with medium alone, or in the presence of anti-IRS or anti-CD3 mAbs followed by GAM to obtain optimal crosslinking of the corresponding surface molecule, as indicated in "Results," was evaluated by enzyme-linked immunosorbent assay (ELISA; PeproTech, London, United Kingdom). ${ }^{32}$

\section{Cytolytic assays}

Cytolytic activity of either ex vivo-isolated PBMCs from patients with $\mathrm{PNH}$ or healthy donors or from T-cell clones was tested in a 4-hour ${ }^{51} \mathrm{Cr}$-release assay as previously described. ${ }^{28,29} \mathrm{~T}$-cell clones were selected for the expression of activating forms of either KIR and/or CLIR, and were used as effector cells with the $\mathrm{Fc} \gamma \mathrm{R}^{+}$murine mastocytoma cell line P815 in the presence of $\mathrm{mAb}$ directed against activating receptor for HLA, at an E/T ratio of 2:1, in a final volume of $200 \mu \mathrm{L}$ RPMI 1640 medium in V-bottomed microwells. ${ }^{28,29}$ In order to confirm that killing of target cells by an IRS ${ }^{+}$ T-cell population or by a T-cell clone is mediated by the ligation of an activating type IRS to its cognate HLA ligand, we used the HLA-I-negative lymphoblastoid cell line 721.221. These cells were transfected either with HLA-G (to induce expression of HLA-E with HLA-G peptides, as appropriate for the CD94/NKG2 complex of activating type); or with HLA-Cw3 (appropriate for CD158h [KIR2D2S1]); or with HLA-Cw4 (appropriate for CD158j [KIR2DS2]). These cells were then used without and with the addition of either anti-HLA-I or anti-IRS $\mathrm{mAb}(5 \mu \mathrm{g} / \mathrm{mL})$. In some experiments, to study the spontaneous cytolytic activity of $\mathrm{IRS}^{+} \mathrm{T}$ cells, GPI ${ }^{+}$K562 erythroleukemia cell line (K562wt) and the parental K562 cell line lacking GPI-linked surface molecules (KCRN) generated by Finberg and collaborators ${ }^{33}$ were used in cytolytic assays with IRS ${ }^{+}$T cells from patients with PNH. To evaluate the contribution of GPI-linked molecules to the interaction between effector and K562 target cells, the experiments were carried out also in the presence of saturating amounts of anti-LFA1 mAb $(5 \mu \mathrm{g} / \mathrm{mL})$.

\section{Analysis of KIR genotype and HLA-I typing in patients with PNH}

High-molecular-weight DNA was extracted from peripheral-blood samples by a standard method. KIR genotyping was performed by using a multiplex polymerase chain reaction (PCR) method developed by Sun et al. ${ }^{34}$ PCR amplification was performed with hot-start DNA polymerase, AmpliTaq Gold (Applied Biosystems), by using the described PCR conditions ${ }^{34}$ and the mixtures of KIR-allele-specific primers kindly provided by D. Senitzer (City of Hope National Medical Center, Duarte, CA). The presence of selected alleles was confirmed by using primers and PCR conditions described by Hiby et al. ${ }^{35}$ As a quality control of our KIR genotyping procedures, we used cell lines with known KIR genotypes (NK/KIR Phase II QC Reference Panel, International Histocompatibility Working Group, Seattle, WA). HLA-I typing was determined by PCR using the commercial kit from One Lambda (Dynal Biotech, Oslo, Norway).

\section{Statistical analysis}

Data are expressed as the mean plus or minus the standard deviation (SD). Nonparametric Mann-Whitney and Fisher exact tests have been used when appropriate. Statistical significance was accepted for $P$ values below 05 .

\section{Results}

Immune-phenotypic analysis of circulating T lymphocytes bearing molecules belonging to the IRS in patients with PNH

In order to identify cells with potential autoreactivity that may be responsible for the depletion of $\mathrm{GPI}^{+}$cells in $\mathrm{PNH}$, we first stained PBMCs from patients with PNH (Table 1) with a panel of monoclonal antibodies directed against different cell-surface markers, including CD3, CD4, CD8, and CD45. No significant differences were found in this respect between patients with $\mathrm{PNH}$ and healthy donors (data not shown). Since it has been recently suggested that in autoimmune diseases $\mathrm{CD}^{+}{ }^{+} \mathrm{IRS}^{+} \mathrm{T}$ cells may be a subset of lymphocytes that is expanded, ${ }^{13-15,22,25}$ we next analyzed the expression of some members of IRS such as CLIR (CD94) and KIR2D (CD158a/h and CD158b/j) together with CD3 (Figure 1A).

In patients with $\mathrm{PNH}$ we found a slight but not statistically significant increase (Mann Whitney, $P<.09$ ) in the percentage of $\mathrm{T}$ cells expressing IRS $\left(\mathrm{CD}^{+} \mathrm{IRS}^{+}\right)$. The absolute number of $\mathrm{T}$ $\mathrm{CD}^{+}{ }^{-} \mathrm{IRS}^{+}$cells in most patients with $\mathrm{PNH}$ was similar to that in healthy donors (Mann Whitney, $P>.4$; Table 2). On the other hand, the absolute number of NK cells $\left(\mathrm{CD}^{-}{ }^{-} \mathrm{IRS}^{+}\right)$was markedly reduced in patients with $\mathrm{PNH}$ (Table 2; Mann-Whitney, $P<.002$ for $\mathrm{CD}^{-}{ }^{-} \mathrm{KIR}_{2} \mathrm{D}^{+}$and $P<.006$ for $\mathrm{CD}^{-}{ }^{-} \mathrm{CLIR}^{+}$).

The number of lymphocytes that fail to express the GPIanchored protein CD59 is much lower in these patients than the number of $\mathrm{CD}^{+}{ }^{+} \mathrm{IRS}^{+}$cells (not shown). We infer that they do not belong to the PNH clone.

Further characterization of $\mathrm{CD}^{+}{ }^{+} \mathrm{IRS}^{+}$cells from patients with PNH demonstrates that they expressed CD8 and CD57 (Figure 1B). This finding suggests that $\mathrm{CD}^{+}{ }^{+} \mathrm{IRS}^{+}$cells may have a cytolytic function. Indeed, $\mathrm{CD} 8{ }^{+} \mathrm{CD} 57^{+} \mathrm{T}$ cells with morphologic features of large granular lymphocytes (LGLs) have been reported in patients with PNH. ${ }^{36-38}$ The granules of LGLs are known to contain perforins, and we have confirmed that in patients with $\mathrm{PNH}$, $\mathrm{CD}^{+}{ }^{\mathrm{IRS}}{ }^{+} \mathrm{T}$ cells express perforins in their cytoplasm (not shown). In addition, by using antibodies specific for individual V $\beta$ TCR families, we have found considerable heterogeneity of IRS $^{+} \mathrm{T}$ cells within individual patients and among different patients (data not shown). 
A

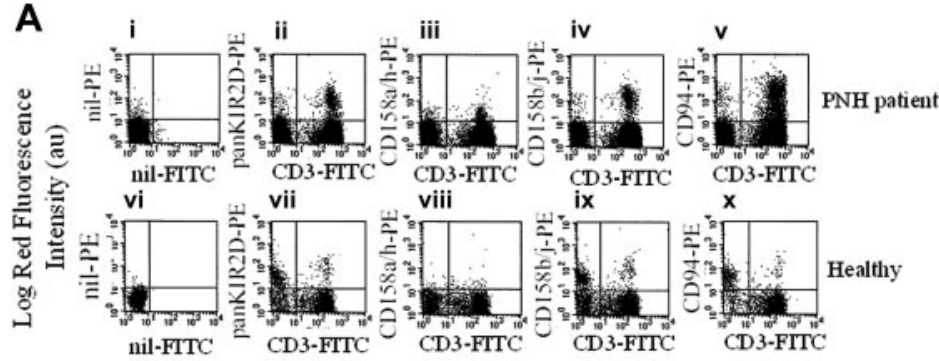

B Log Green Fluorescence Intensity (au)

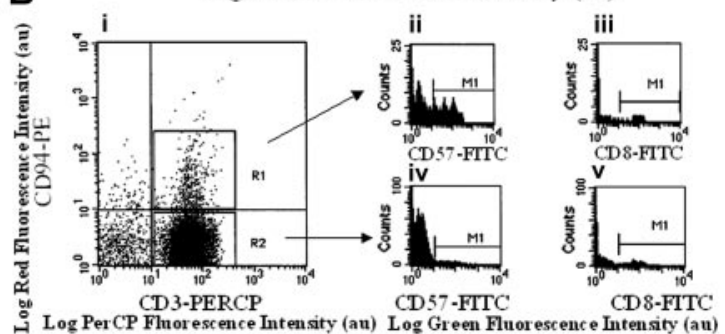

Figure 1. Immune phenotypic analysis of circulating lymphocytes in PNH patients. (A) Expression of IRS members on peripheral-blood T lymphocytes from a patient with PNH. Peripheral-blood mononuclear cells isolated from patient PNH5 (Ai-v) or healthy donor HD3 (Avi-x) were stained with either anti-pan-KIR2D mAb (Aii, Avii), anti-CD158a/h mAb (Aiii, Aviii), anti-CD158b/j mAb (Aiv, Aix), or anti-CLIR (CD94) mAb (Av, Ax) and anti-CD3 mAb (Aii-Av, Avii-Ax) followed by anti-isotype specific goat antimouse antiserum PE-conjugated (for anti-IRS mAbs) or FITC-conjugated (for anti-CD3 mAb). Samples were run on a FACSort and at least 10000 events were analyzed with the CellQuest computer program (Becton Dickinson). Panels Ai and Avi were stained with an unrelated mAb followed by the second reagent. Results are expressed as Log

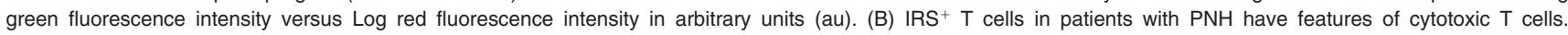
Peripheral-blood mononuclear cells (PNH5) were stained with PE-conjugated anti-CD94 mAb, PerCP-conjugated anti-CD3 (Bi), and either FITC-conjugated anti-CD57 (Bii, Biv) or anti-CD8 (Biv, Biii) mAb. Samples were run on a FACSort and analyzed with the CellQuest program. R1 and R2 regions (Bi), corresponding to CD3 ${ }^{+} \mathrm{CD} 94^{+}$and $\mathrm{CD}^{+}{ }^{+} \mathrm{CD} 94^{-}$cells respectively, were depicted to analyze the third color (CD57- or CD8-FITC-conjugated; Bii-Bv). Results are expressed as Log PerCP fluorescence intensity versus Log red (PE) fluorescence intensity in arbitrary units (au) (Bi) or Log green (FITC) fluorescence intensity versus number of cells (Bii-Bv). Similar proportions of the different T-cell subsets were found in 3 additional patients with $\mathrm{PNH}$ analyzed.

\section{The engagement of IRS molecules on IRS ${ }^{+} \mathbf{T}$ cells from patients with PNH triggers a powerful cytolytic activity}

Lymphocytes can express 2 different isoforms of IRS, one of which is of the activating type and the other of the inhibiting type with respect to cytolytic function. ${ }^{15-18,39}$ Thus, we analyzed the function of IRS in T cells from patients with PNH. To address this point, we used a redirected killing assay. In this assay, the engagement of the corresponding molecule by an appropriate (anti-IRS) mAb acts both as a bridge between the Fc $\gamma$ receptor of P815 cells and a surface molecule on $\mathrm{T}$ cells and as a cross-linking device that triggers the function of $\mathrm{T}$ cells themselves. In general, among PBMCs, the $\mathrm{CD}^{-}{ }^{-} \mathrm{CD} 16^{+} \mathrm{NK}$ cells, on which IRSs have been first described, are the most potent cytolytic effector cells. ${ }^{15-17}$ In order to minimize interference in this assay by NK cells, we selected those samples with a low number of NK cells. We found that ex vivo-isolated PBMCs from 2 patients with $\mathrm{PNH}$, incubated with either anti-KIR or anti-CLIR mAbs in a redirected killing assay, displayed a strong lytic effect against the target cells, indicating that their IRSs are predominantly of the activating type (Figure 2).

When we used the same assay to test highly purified $\mathrm{IRS}^{+} \mathrm{T}$ cells activated by IL2 from patients with PNH $(n=4)$, we observed that either anti-KIR or anti-CLIR mAbs induced a strong lytic activity (data not shown). Taken together, these findings indicate that, in patients with $\mathrm{PNH}$, T cells are equipped with activating IRS. ${ }^{18-20}$

\section{T-cell clones from patients with PNH mainly express activating isoforms of IRS molecules}

In order to determine the relative proportions of activating versus inhibiting isoforms of IRS present on T cells in patients with PNH, we proceeded to isolate T-cell clones. This was done by purifying $\mathrm{CLIR}^{+}$cells from patients with $\mathrm{PNH}$ and healthy donors by positive immune-magnetic selection using anti-CLIR mAb. CLIR ${ }^{+}$ cells were cloned by limiting dilution and cultured with IL2. ${ }^{28,29}$ The percentage of $\mathrm{CD}^{+}$cells among newly isolated $\mathrm{CLIR}^{+}$cells ranged from $80 \%$ to $95 \%$. The cloning efficiency was lower $(25 \%)$ in patients with $\mathrm{PNH}$ than that found with $\mathrm{CD}^{+} \mathrm{CD}^{+}$or $\mathrm{CD}^{+}{ }^{+} \mathrm{CD}^{+}{ }^{+} \mathrm{T}$ cells from healthy donors $(70 \%$ and $95 \%$, respectively), but it was similar to that of $\mathrm{CLIR}^{+}$cells from healthy donors (27\%; data not shown). As expected, the large majority of these T-cell clones, whether derived from patients with $\mathrm{PNH}$ or from healthy donors, expressed CLIR, whereas only a minority expressed KIR molecules (not shown).

In a redirected killing assay, a given clone was classified as being of the activating type when anti-KIR or anti-CLIR mAb triggered cytolysis of $\mathrm{P} 815$ at an $\mathrm{E} / \mathrm{T}$ ratio of $2: 1$, whereas a clone was classified as being of the inhibiting type if it inhibited lysis of P815 at an E/T ratio of 20:1.

We found that the large majority of $\mathrm{CD}^{+}{ }^{+} \mathrm{IRS}^{+} \mathrm{T}$-cell clones from patients with $\mathrm{PNH}$ expressed activating isoforms of IRS (Figure 3). In some $\mathrm{CD}^{+}{ }^{+} \mathrm{IRS}^{+} \mathrm{T}$-cell clones, both KIR and CLIR were of the activating type, whereas other T-cell clones bore activating CLIR but inhibiting KIR or vice versa (not shown). Twenty-four of 45 of the T-cell clones derived from patients with PNH bore only KIR of the activating type (from PNH5, 12 CD158h [KIR2DS1] and 2 CD158j [KIR2DS2] of $23 \mathrm{KIR}^{+}$clones; from PNH6, 5 CD158h [KIR2DS1] of $10 \mathrm{KIR}^{+}$clones; from PNH7, 5 CD158j [KIR2DS2] of $12 \mathrm{KIR}^{+}$clones). Forty-five of 65 T-cell clones bore CLIR of the activating type (17 from PNH5, 13 from PNH6, and 15 from PNH7). By contrast, in healthy donors T-cell clones bearing the activating isoforms of these 2 IRSs were very rare (only 1 of 21 and 2 of 43, respectively, bore either KIR or CLIR of the activating type; Figure 4A; Fisher exact test, $P<.001)$.

The majority (about 90\%) of clones from patients with PNH bearing activating IRS were TCR $\alpha \beta$ and a few were TCR $\gamma \delta$. These findings indicate that T-cell clones expressing activating IRS are present with high frequency in patients with $\mathrm{PNH}$, whereas they are an exception in healthy donors. ${ }^{13-15}$

\section{The engagement of activating IRS on IRS ${ }^{+} \mathrm{T}$-cell clones from patients with PNH induces production of high levels of IFN- $\gamma$ and TNF- $\alpha$}

Given the expression of activating IRS on T-cell clones derived from patients with $\mathrm{PNH}$, we further analyzed whether the ligation of these IRSs lead to the production of cytokines potentially involved in the regulation of hematopoiesis. Indeed, it has been shown that IFN- $\gamma$ and TNF- $\alpha$ may play a key role in suppressing 
Table 2. Quantitative analysis of the expression of molecules belonging to the IRS on T and NK lymphocytes from patients with PNH

\begin{tabular}{|c|c|c|c|c|c|c|}
\hline Patient no. & $\begin{array}{l}\mathrm{CD}^{+} \mathrm{KIR}^{\mathrm{K}} \mathrm{D}^{+} \\
\text {cell } / \mu \mathrm{L}\end{array}$ & $\begin{array}{l}\text { CD3- }^{-} \text {KIR2D }^{+} \\
\text {cell } / \mu \mathrm{L}\end{array}$ & $\begin{array}{l}\mathrm{CD}^{+} \mathrm{KIR}^{\mathrm{K}} \mathrm{D}^{+}, \% \\
\text { of T cells }\end{array}$ & $\mathrm{CD}^{+}{ }^{+} \mathrm{CLIR}^{+}$, cell $/ \mu \mathrm{L}$ & 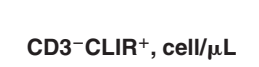 & $\begin{array}{c}\mathrm{CD3}^{+}{ }^{+} \mathrm{CLIR}^{+}, \% \text { of } \\
\text { T cells }\end{array}$ \\
\hline \multicolumn{7}{|l|}{ PNH1 } \\
\hline Sample 5 & 98 & 91.6 & 2.9 & - & - & - \\
\hline Sample 3 & - & - & - & 31.3 & 27.3 & 3.1 \\
\hline \multicolumn{7}{|l|}{ PNH2 } \\
\hline Sample 2 & 195 & 69 & 20.6 & - & - & - \\
\hline \multicolumn{7}{|l|}{ PNH3 } \\
\hline Sample 5 & 51 & 30.6 & 3.7 & - & - & - \\
\hline Sample 3 & - & - & - & 64 & 42 & 4.8 \\
\hline \multicolumn{7}{|l|}{ PNH4 } \\
\hline Sample 1 & 55 & 10 & 9.2 & - & - & - \\
\hline \multicolumn{7}{|l|}{ PNH5 } \\
\hline Sample 2 & 52.5 & 206 & 3.8 & - & - & - \\
\hline \multicolumn{7}{|l|}{ PNH6 } \\
\hline Sample 4 & 70.2 & 10 & 8.3 & - & - & - \\
\hline Sample 2 & - & - & - & 115.5 & 9.5 & 12.7 \\
\hline \multicolumn{7}{|l|}{ PNH7 } \\
\hline Sample 4 & 61.8 & 80.3 & 5.8 & - & - & - \\
\hline Sample 2 & - & - & - & 112.5 & 87 & 8.4 \\
\hline \multicolumn{7}{|l|}{ PNH8 } \\
\hline Sample 2 & 57.5 & 69.5 & 3.8 & - & - & - \\
\hline \multicolumn{7}{|l|}{ PNH9 } \\
\hline Sample 3 & 71.3 & 174.7 & 5 & - & - & - \\
\hline Sample 1 & - & - & - & 87 & 204 & 6.9 \\
\hline \multicolumn{7}{|l|}{ PNH10 } \\
\hline Sample 1 & 29 & 10 & 2.9 & - & - & - \\
\hline \multicolumn{7}{|l|}{ PNH11 } \\
\hline Sample 4 & 151.3 & 111.8 & 15.3 & - & - & - \\
\hline Sample 3 & - & - & - & 177.3 & 73.0 & 17.0 \\
\hline \multicolumn{7}{|l|}{ PNH12 } \\
\hline Sample 1 & 87 & 34 & 9.4 & 67 & 24 & 7.2 \\
\hline \multicolumn{7}{|l|}{ PNH13 } \\
\hline Sample 1 & 31 & 27 & 2.6 & 94 & 56 & 7.9 \\
\hline Mean \pm SD (range) & $81.8 \pm 47.0(31-195)$ & $76.2 \pm 62.7(10-206)$ & $7.5 \pm 5.5(2.6-20.6)$ & $96.3 \pm 43.7(31.3-177.3)$ & $65.4 \pm 61.7(9.5-204.0)$ & $8.5 \pm 4.4(3.1-17.0)$ \\
\hline \multicolumn{7}{|l|}{ Healthy controls ${ }^{\star}$} \\
\hline Mean \pm SD (range) & $63 \pm 36(19-171)$ & $192 \pm 155(8-690)$ & $4.3 \pm 2.4(1.3-11.4)$ & $102 \pm 71(15-309)$ & $214 \pm 155(9-666)$ & $6.8 \pm 4.7(1.0-20.6)$ \\
\hline
\end{tabular}

Peripheral-blood lymphocytes were isolated from the indicated patients. Samples of blood were collected at about 3 months from one to another during the follow-up; the sample number indicates the number of the blood collection. Samples were stained with anti-CD3 mAb and anti-panKIR2D mAb (NKVFS1) or anti-CLIR mAb followed by isotype-specific antimouse antiserum. At least 10000 events for each sample were analyzed on a FACSort (Becton Dickinson). Percent of CD3 ${ }^{+} \mathrm{T}$ lymphocytes that are $\mathrm{KIR}_{2} \mathrm{D}^{+}$or CLIR is also shown.

— indicates that the sample was not stained with the indicated antibody combination.

*For healthy controls, $n=38$ for CD3/KIR2D staining, and $n=17$ for CD3/CLIR staining.

hematopoiesis in AA. ${ }^{40-44}$ To analyze whether T-cell clones bearing activating IRS were able to produce IFN- $\gamma$ and TNF- $\alpha$, we stained these clones with either anti-CLIR or anti-KIR mAbs; thus, these clones were incubated for 24 hours at $37^{\circ} \mathrm{C}$ on GAM-coated plates to achieve the cross-linking of the corresponding IRS. As shown in Figure 5, both IFN- $\gamma$ and TNF- $\alpha$ were produced by IRS ${ }^{+}$T-cell clones upon the engagement of either CLIR or KIR on the cell surface. It is of note that the amount of IFN- $\gamma$ or TNF- $\alpha$ released in culture supernatant was comparable to that elicited by the engagement of the CD3/TCR complex achieved by using anti-CD3 mAb, in the same experimental system. T-cell clones that bore only one member of IRS of the activating type were able to produce the IFN- $\gamma$ and TNF-A cytokines only when the corresponding receptor was engaged by the specific mAb (data not shown). These findings suggest that activating IRS, when appropriately engaged by the corresponding natural ligand, can induce not only activation of the cytolytic machinery, but also the release of cytokines, which may play a role in regulating hematopoiesis.

\section{T cells expressing activating IRS lyse target cells bearing the cognate IRS counter-receptors}

721.221 cells do not express HLA class I molecules but, once transfected with HLA-G, they will express HLA-E, the counterligand for CD94/NKG2-presenting HLA-G-derived peptides. When we exposed 721.221 lymphoblastoid cells transfected with HLA-G to T-cell populations from patients $\mathrm{PNH6}, \mathrm{PNH} 7$, and $\mathrm{PNH} 11$, who expressed the CLIR CD94/NKG2 of the activating type, we obtained lysis in all 3 cases (Figure 5). Addition of either anti-HLA class I or anti-CD94 mAb to the cytolytic assay strongly inhibited lysis (Figure 5A-C). To determine that also activating KIRexpressing T cells lyse cells bearing KIR ligand, we selected T-cell clones from patients with $\mathrm{PNH}$ that express only one activating KIR. Clone B25.5 CD158j ${ }^{+}\left(\mathrm{KIR}_{2} \mathrm{DS} 2^{+}\right)$from patient PNH7 killed 721.221 cells transfected with the counter-ligand HLA-Cw3 allele (Figure 5D); and clone C15.10 CD158h ${ }^{+}\left(\mathrm{KIR}_{2} \mathrm{DS} 1^{+}\right)$ from patient PNH5 killed 721.221 cells transfected with the 
A

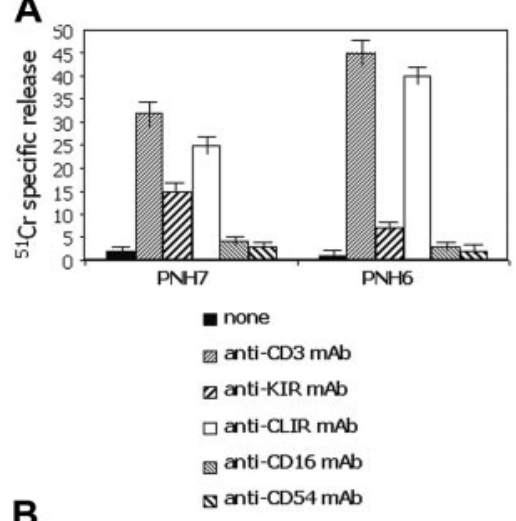

B

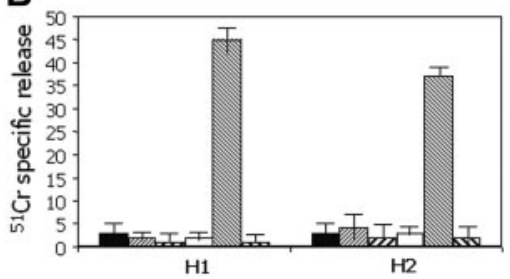

Figure 2. Peripheral-blood mononuclear cells from patients with PNH have strong cytolytic activity. Peripheral-blood mononuclear cells were isolated from either patients with $\mathrm{PNH}(\mathrm{A})$ or healthy donors $(\mathrm{B})$ and their cytolytic activity was analyzed in a 4-hour redirected killing assay using the $F c \gamma R^{+}$murine cell line P815 in the absence (none) or in the presence of mAbs recognizing the indicated surface molecules. Anti-CD54 mAb was used as an isotype-matched control mAb. The PNH donor samples (PNH6 and $\mathrm{PNH} 7$ ) used in this experiment had a low number of $\mathrm{CD}_{16}{ }^{+} \mathrm{NK}$ cells $(9$ cells/ $\mu \mathrm{L}$ in $\mathrm{PNH} 6$ and 24 cells $/ \mu \mathrm{L}$ in $\mathrm{PNH} 7$ ) but sizeable proportions of $\mathrm{CD}^{+} \mathrm{IRS}^{+}$cells (109 cells/ $\mu \mathrm{L}$ in $\mathrm{PNH} 6$ and 112 cells $/ \mu \mathrm{L}$ in $\mathrm{PNH} 7$ ). Cytolytic activity of peripheral-blood lymphocytes from 2 representative healthy donors ( $\mathrm{H} 1$ and $\mathrm{H} 2)$ is shown for comparison (B). Results are expressed as \% ${ }^{51} \mathrm{Cr}$-specific release at an E/T ratio of 10:1 mean of triplicate samples; bars indicate standard deviation of triplicate samples. A comparable difference between PBMCs of patients with $\mathrm{PNH}$ and healthy donors was found also at $20: 1$ and at $40: 1 \mathrm{E} / \mathrm{T}$ ratios.

corresponding ligand HLA-Cw4 (Figure 5E). Again, the addition of anti-HLA-I or anti-pan KIR mAbs inhibited by $50 \%$ to $60 \%$ the lysis of target cells bearing the KIR counter-ligands (Figure 5D-E). As a negative control, we found that clone A14.25, expressing the inhibiting KIR2DL1, did not lyse 721.221 Cw4-transfected cells, unless the inhibiting signal delivered via KIR2DL1 was impaired by the addition of anti-HLA-I or anti-KIR mAb.

\section{Matching activating KIR genotypes and HLA-C genotypes in patients with $\mathrm{PNH}$}

$\mathrm{IRS}^{+}$molecules can exert their action only when they find the appropriate counter-ligands on target cells. Both the CLIR gene and its counter-ligands (ie, HLA-G and HLA-E) are not known to be polymorphic: therefore, a match for CLIR is always potentially available. In contrast, the genes encoding KIR molecules as well as those encoding their counter-ligands $(H L A-C)$ are polymorphic. In fact, each $K I R$ allele can exert its effect only if it finds on the target cell at least one HLA-C molecule that is a specific match for it. Therefore, we proceeded to determine both the activating KIR genotypes and the $H L A-C$ genotypes of patients with PNH (Table 3). In patients PNH4, PNH5, PNH6, and PNH9, we found KIR2DS1 and 1 or 2 of its counter-ligands (HLA-Cw4, HLA-Cw5, Cw6). In patients $\mathrm{PNH} 3, \mathrm{PNH} 5, \mathrm{PNH} 7$, and $\mathrm{PNH} 9$, we found KIR2DS2 and 1 or 2 of its counter-ligands (HLA-Cw1, HLA-Cw7, $H L A-C w 8)$. In patients PNH1, PNH2, PNH4, and PNH12, we found the KIR2DS4 gene and its counter-ligand $H L A-C w 4 .{ }^{45}$ Thus, in 9 of 11 patients with PNH we found both the activating KIR gene and the appropriate $H L A-C$ allele, so that target cells bearing the latter would be susceptible to KIR-mediated killing. We note that the 2 remaining patients (PNH11 and PNH13) share the KIR2DS4 gene, for which a possible alternative (non-MHC) counter-ligand has been recently suggested. ${ }^{46}$

\section{Different susceptibility to lysis of $\mathrm{GPI}^{+}$versus $\mathrm{GPI}^{-}$cells}

In patients with PNH there is an expansion of hematopoietic cells lacking GPI-linked molecules. ${ }^{47-50}$ This is thought to result not from an intrinsic growth advantage of $\mathrm{GPI}^{-}$precursors, but rather from negative selection against $\mathrm{GPI}^{+}$precursors by autoreactive cells. ${ }^{47-52}$ Therefore, we next tested whether IRS $^{+} \mathrm{T}$ cells from patients with $\mathrm{PNH}$ would exert a different spontaneous cytolytic activity against $\mathrm{GPI}^{+}$versus $\mathrm{GPI}^{-} \mathrm{K}^{-} 62$ cells. As shown in Figure 6 , the cytolytic activity exerted by $\mathrm{IRS}^{+} \mathrm{T}$ cells from 3 different patients with $\mathrm{PNH}$ against $\mathrm{GPI}^{+} \mathrm{K} 562$ was consistently higher (ranging from $15 \%$ to $55 \%$ ), at different $\mathrm{E} / \mathrm{T}$ ratios, than that observed using $\mathrm{GPI}^{-} \mathrm{K}^{-} 62$ cell line. It is well known that the binding between LFA-1 on effector lymphocytes and intercellular adhesion molecule-1 (ICAM-1) expressed on target cells plays a key role in triggering cytolytic activity. ${ }^{53-55}$ Pretreatment of cells
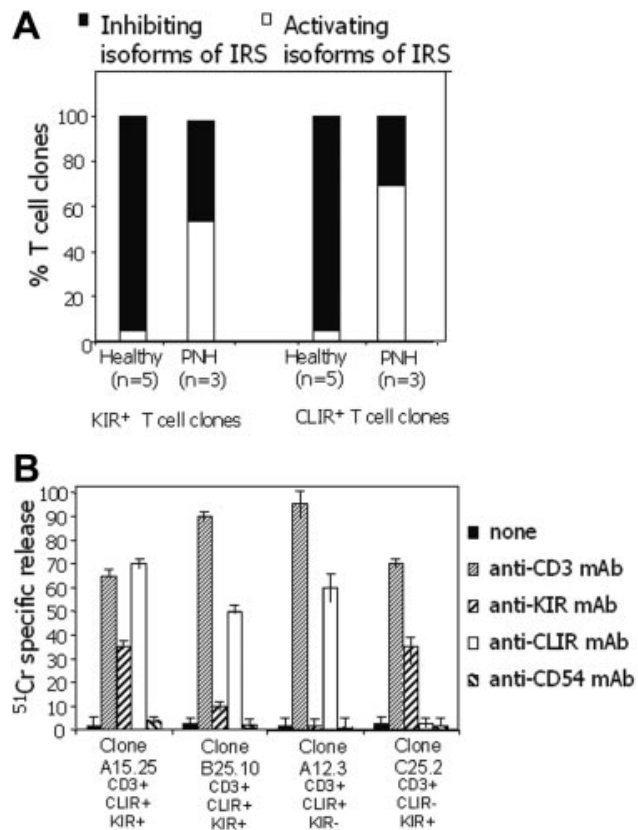

Figure 3. Most IRS ${ }^{+}$T-cell clones from patients with PNH bear IRS of the activating type. T-cell clones expressing IRS were derived from 3 different patients with PNH (PNH5, PNH6, PNH7) and from 5 healthy donors (HD3, HD8, HD9, HD15, HD19). (A) Each clone was analyzed in redirected killing assay using P815 target cells in the presence of anti-CLIR or anti-KIR mAbs at (1) an E/T ratio of 20:1 to identify T-cell clones bearing inhibiting IRS isoforms $(\square)$ and (2) an $E / T$ ratio of 2:1 to identify T-cell clones bearing activating IRS isoforms ( $\square$ ). (B) Cytolysis by T-cell clones obtained from patients with $\mathrm{PNH}$ upon the engagement of activating IRS. Cytolytic activity of T-cell clones derived from patients with $\mathrm{PNH}$ was analyzed in a 4-hour redirected killing assay in the absence (none) or in the presence of anti-CLIR or anti-KIR mAb or anti-CD3 mAb. Anti-CD54 mAb was used as an isotype-matched control mAb. The clone A15.25 (PNH5) was CLIR ${ }^{+} \mathrm{KIR}_{2} \mathrm{DS} 1^{+}\left(\mathrm{CD}^{+58 \mathrm{~h}^{+}}\right)$and B25.10 (PNH7) was CLIR ${ }^{+} \mathrm{KIR}_{2} \mathrm{DS}{ }^{+}\left(\mathrm{CD}^{2} \mathrm{Cj}^{+}\right)$while the clones from $\mathrm{PNH} 6 \mathrm{~A} 12.3$ expressed only CLIR (CD94) and the clone C25.2 was CLIR ${ }^{-}$KIR2DS1 ${ }^{+}$. All the clones were selected for the expression of activating isoforms of either CLIR and/or $\mathrm{KIR}$. These clones are representative of 65 clones analyzed. Results are expressed as $\%$ of ${ }^{51} \mathrm{Cr}$ release, mean of triplicate samples; bars indicate standard deviation of triplicate samples. 

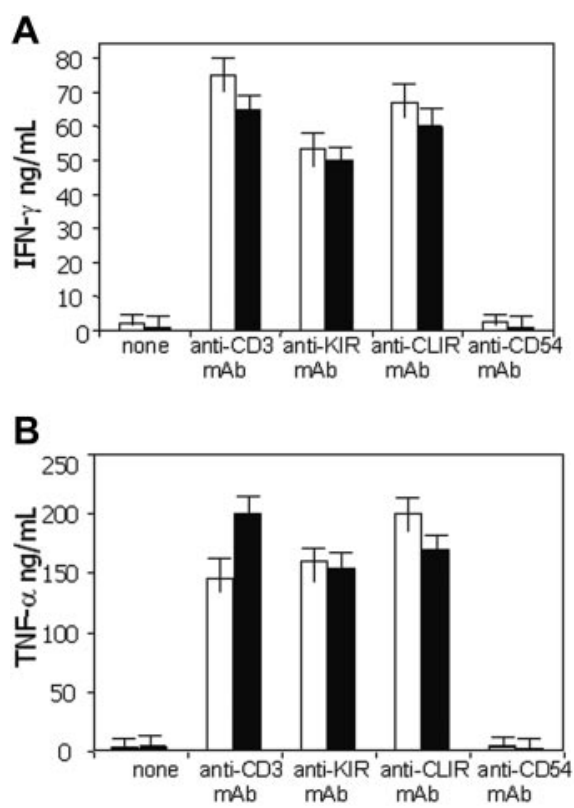

Figure 4. IRS ${ }^{+}$T-cell clones produce a high amount of IFN- $\gamma$ and TNF- $\alpha$. T-cell clones expressing IRS activating isoforms $\left(\mathrm{CD}^{+} \mathrm{KIR}^{+} \mathrm{CLIR}{ }^{+}\right.$clones: $\mathrm{C} 3.50$ [KIR2DS2 ${ }^{+}$, from PNH5], $\mathbf{\square}$; and A1.25 [KIR2DS1 ${ }^{+}$, from PNH6], $\square$ ) were stained with either anti-CD3, anti-KIR, anti-CLIR, or anti-CD54 (isotype-matched control $\mathrm{mAb}$ ) $\mathrm{mAbs}$ and incubated in plates precoated with goat antimouse antiserum. After 24 hours, culture supernatants were harvested and analyzed by ELISA for the presence of either IFN- $\gamma(\mathrm{A})$ or TNF- $\alpha$ (B). "None" represents the release of either IFN- $\gamma$ or TNF- $\alpha$ in the absence of any mAb. Results are expressed as mean of triplicate samples; bars indicate standard deviation of triplicate samples.

with lymphocyte function-associated antigen 1 (LFA-1)-specific mAbs strongly reduced lysis of both $\mathrm{GPI}^{+}$and $\mathrm{GPI}^{-} \mathrm{K} 562$ cell lines, confirming that LFA-1/ICAM-1 binding is involved in effector-target interaction. However, in the presence of anti-LFA-1 $\mathrm{mAb}, \mathrm{IRS}^{+} \mathrm{T}$ cells from patient PNH11 were still able to lyse K562 cells, but only if they were GPI ${ }^{+}$(Figure 6C).

These results indicate that lack of surface GPI molecules renders cells less susceptible to lysis mediated by cytolytic effector $\mathrm{T}$ lymphocytes, suggesting that GPI-linked molecules have a critical role in effector-target ligation.

\section{Discussion}

The classic clinical triad of PNH consists of intravascular hemolysis, thrombosis, and bone marrow failure. ${ }^{52,53}$ At the molecular level, PNH is characterized by the deficiency on the surface of blood cells of all proteins anchored to the membrane by the glycosylphosphatidylinositol (GPI) molecule. The absence of GPIlinked molecules, such as CD59 and CD55, explains hemoglobinuria, ${ }^{56,57}$ and probably also the tendency to thrombosis. ${ }^{58}$ On the other hand, there is no obvious explanation as to why deficiency of GPI-linked proteins by itself ought to also cause bone marrow failure. A plausible model has been, for some time, that an autoimmune process is at work in $\mathrm{PNH}$, as it is in idiopathic aplastic anemia (IAA) ${ }^{8,40}$ If the auto reactive $\mathrm{T}$ cells involved in this process recognize a GPI-linked protein, or the GPI molecule itself, then $\mathrm{GPI}^{+}$cells, including $\mathrm{GPI}^{+} \mathrm{HSCs}$, would be damaged selectively; whereas $\mathrm{GPI}^{-}$HSCs, if they exist, would escape damage and be able to proliferate. ${ }^{59}$ This model has been corroborated by the finding that small $\mathrm{GPI}^{-}$(ie, $\mathrm{PNH}-$ like) clones exist in the peripheral blood of healthy subjects ${ }^{48}$; therefore, in PNH it is the expansion rather than the presence of $\mathrm{GPI}^{-}$cells that we need to explain. Based on this notion, it was natural to seek evidence for auto reactive $\mathrm{T}$ cells. In fact, it has emerged that skewing of the T-cell repertoire is common in $\mathrm{PNH},{ }^{9-10}$ and the coexistence of LGL leukemia and PNH in the same patient ${ }^{38}$ suggests that the T cells responsible for bone marrow damage in PNH may belong to the $\mathrm{CD}^{+}{ }^{+} \mathrm{CD} 8{ }^{+} \mathrm{CD} 57^{+}$cell population displaying NK-like cytolytic activity. ${ }^{15-17}$

NK-like T cells can express IRS molecules. In terms of their structure, IRSs are of 2 types: the immunoglobulin (Ig) superfamily inhibitory receptors (ISIRs), which include killer Ig-like receptors (KIR, CD158a, b, and p50); and C-type lectin inhibitory receptors (CLIRs), ${ }^{15-17}$ such as the CD94/NKG2 complex. An increase of T cells expressing IRS has been reported in a range of chronic disorders, in which they may serve to maintain memory $\mathrm{T}$ cells alive, as well as in a case of pure red-cell aplasia. ${ }^{60}$

For this reason, we have systematically studied in patients with PNH those NK-like T cells that carry IRS molecules. We have
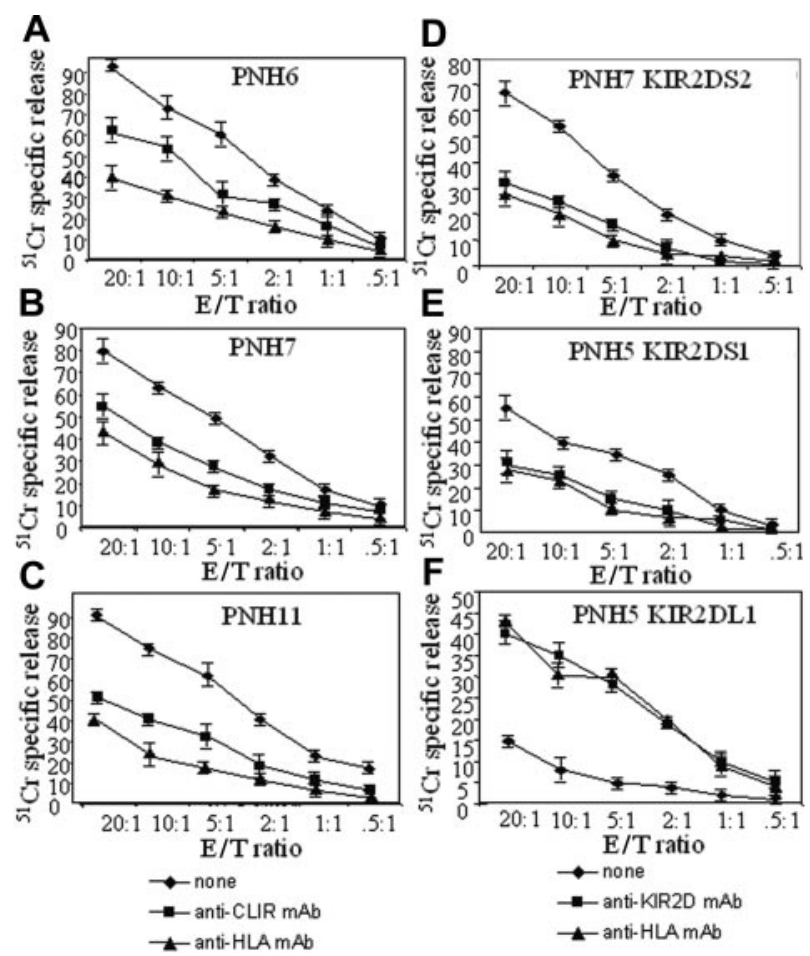

Figure 5 . $\mathrm{CD}^{+}{ }^{+} \mathrm{RS}^{+} \mathrm{T}$ cells lyse target cells bearing the appropriate HLA-I counter ligand. Polyclonal (A: $\mathrm{PNH}$; $\mathrm{B}$ : $\mathrm{PNH} 7$; $\mathrm{C}$ : $\mathrm{PNH} 11$ ) bulk populations homogeneously expressing CD3 and CLIR $\left(\mathrm{CD}^{+}\right)$antigens were challenged in a 4-hour ${ }^{51} \mathrm{Cr}$ release assay with 721.221 target cells bearing HLA-E with G peptides as ligand for CD94/NKG2 complex of the activating type. Anti-HLA-I mAb or anti-CD94 $\mathrm{mAb}(5 \mu \mathrm{g} / \mathrm{mL})$ was added to the cytolytic assay to determine whether the masking of CD94/NKG2-HLA-I interaction leads to inhibition of target lysis. (D-F) The $\mathrm{CD}^{+} \mathrm{KIR}^{+} \mathrm{CLIR}^{-} \mathrm{T}^{-}$cell clones KIR2DS2 ${ }^{+}$(D; from PNH7) or KIR2DS1 ${ }^{+}$(E; from $\mathrm{PNH5}$ ) were used as effector cells with the 721.221 transfected with HLA-Cw3 or HLA-Cw4 (ligands of KIR2DS2 or KIR2DS1, respectively). E/T ratio indicates effector-target ratio. Anti-HLA-I mAb or anti-panKIR2D mAb $(5 \mu \mathrm{g} / \mathrm{mL})$ was added to the cytolytic assay to determine whether the masking of KIR2D-HLA-I interaction leads to inhibition of target lysis. The $\mathrm{CD}^{+}{ }^{+} \mathrm{KIR}^{+} \mathrm{T}$-cell clone expressing KIR2DL1, the inhibiting form of KIR2D recognizing HLA-Cw4, was challenged with 721.221 target cells HLA-Cw4 transfected. In this instance, the addition of anti-HLA-I mAb or anti-panKIR2D mAb $(5 \mu \mathrm{g} / \mathrm{mL})$ led to triggering of lysis as the impairment of KIR2D-HLA-I binding does not protect the target cells any more. Results are expressed as $\%{ }^{51} \mathrm{Cr}$-specific release, mean of triplicate samples plus or minus SD. 
Table 3. The genotype of activating KIR and of HLA-C in $\mathrm{PNH}$ patients

\begin{tabular}{|c|c|c|}
\hline Patient no. & Activating $K I R$ genotype & $H L A-C$ allele \\
\hline $\mathrm{PNH} 1$ & $2 D S 4$ & $04, \ddagger 16$ \\
\hline $\mathrm{PNH} 2$ & $2 D S 4$ & $04, \ddagger 07$ \\
\hline $\mathrm{PNH3}$ & $2 D S 2,+2 D S 4$ & $08,+12$ \\
\hline $\mathrm{PNH} 4$ & $2 D S 1,{ }^{*} 2 D S 2,2 D S 3,2 D S 4, \neq 2 D S 5,3 D S 1$ & $04, \mp 06$ \\
\hline $\mathrm{PNH} 5$ & $2 D S 1,{ }^{*} 2 D S 2,+2 D S 3,3 D S 1$ & $04,{ }^{*} 07 t$ \\
\hline $\mathrm{PNH} 6$ & $2 D S 1,{ }^{*} 2 D S 3,2 D S 4,3 D S 1$ & $05,{ }^{*} 15$ \\
\hline $\mathrm{PNH7}$ & $2 D S 2,+2 D S 3,2 D S 4$ & $01,+07 t$ \\
\hline $\mathrm{PNH9}$ & $2 D S 1,{ }^{*} 2 D S 2,+2 D S 3,2 D S 4,2 D S 5,3 D S 1$ & $06,{ }^{*} 07 t$ \\
\hline $\mathrm{PNH} 11$ & $2 D S 4$ & 07,07 \\
\hline $\mathrm{PNH} 12$ & 2DS4‡ & $03,04 \ddagger$ \\
\hline $\mathrm{PNH} 13$ & $2 D S 4$ & 06,15 \\
\hline
\end{tabular}

Patients as in Table 1. The ligands of KIR2DS1 are the HLA-CLys80 (w2, w4, w5, w6); the ligands of KIR2DS2 are the HLA-C ${ }^{A s n 80}$ (w1, w3, w7, w8); the ligand of KIR2DS4 is the HLA-Cw4; the ligands of KIR2DS3 and KIR2DS5 are still unknown.

*Positive matches for KIRDS1.

†Matches for KIR2DS2.

‡Matches for KIRDS4. ${ }^{15-17,45,46}$

observed in these patients a slight but not statistically significant increase of the proportion of $\mathrm{T}$ cells bearing IRS molecules, whereas $\mathrm{CD}^{-} \mathrm{CD} 16^{+} \mathrm{NK}$ cells were decreased, as previously reported. ${ }^{61,62}$ This shortage of NK cells might be part of the bone marrow failure syndrome present in patients with $\mathrm{PNH} .{ }^{63,64} \mathrm{On}$ the other hand, in most patients with PNH the absolute number of IRS ${ }^{+}$ $\mathrm{T}$ cells was similar to that found in healthy controls. These findings were in keeping with a qualitative rather than with a quantitative abnormality of $\mathrm{IRS}^{+} \mathrm{T}$ cells in $\mathrm{PNH}$; therefore, we proceeded to their functional characterization.

IRS molecules exist in 2 functionally different isoforms. In healthy donors, most IRS ${ }^{+}$T cells bear isoforms of IRS molecules with inhibiting properties. In fact, their engagement inhibits strongly cytolytic activity and cytokine production triggered via activating receptors (ie, the CD3/TCR complex). ${ }^{25,26}$ Nevertheless, a small proportion of IRS $^{+} \mathrm{T}$ cells bear isoforms of IRS molecules with activating properties. The physiologic role of the activating isoforms of IRS is incompletely understood, although several hypotheses have been put forward to explain their presence on different lymphocyte subsets. ${ }^{15-17,39}$ Expansion of these cells has been reported in rheumatoid arthritis, ${ }^{24}$ suggesting that they may play a role in some autoimmune process.

Unlike in healthy subjects, in patients with PNH the ligation of IRS molecules either on freshly isolated PBMCs (Figure 3) or on highly purified IL2-activated IRS $^{+} \mathrm{T}$ cells triggered cytolysis in a redirected killing assay. This indicates that in patients with $\mathrm{PNH}$ there is a marked increase in $\mathrm{IRS}^{+} \mathrm{T}$ cells bearing activating isoforms of IRS. This was corroborated by generating T-cell clones. Indeed, from healthy subjects more than $95 \%$ of these clones were of the inhibiting type. In contrast, under the same experimental conditions, in patients with PNH more than $50 \%$ of IRS $^{+}$T-cell clones in our redirected killing assay were of the activating type (Figure 4A). This activating function has been more conclusively confirmed by the finding that the engagement of the activating IRS with the appropriate HLA counter-ligands (HLA-E with G peptide for CLIR; HLA-Cw4 for KIR2DS1; HLA-CW3 for KIR2DS2) triggered the cytolytic activity of $\mathrm{IRS}^{+} \mathrm{T}$ cells (Figure 5). The counter-ligand of the activating CLIR is potentially present in all individuals, whereas activating KIR alleles recognize specific HLA-C alleles. In this respect, our analysis has shown that in most patients with $\mathrm{PNH}$, activating KIR isoforms are properly matched with their HLA-C counter-ligands (Table 3). Although we cannot positively state that HLA-C-matched activating KIR alleles are expressed on $\mathrm{IRS}^{+} \mathrm{T}$ cells, the genotype data suggest that the cytotoxic ability of the IRS ${ }^{+} \mathrm{T}$ cells could occur in vivo.

In principle, we cannot say whether the increase in IRS $^{+} \mathrm{T}$ cells bearing activating IRS isoforms in PNH is a secondary or a primary phenomenon. Earlier reports from other groups and from our group have not revealed $\mathrm{GPI}^{-}$cells to be less sensitive than $\mathrm{GPI}^{+}$cells to T-cell ${ }^{65,66}$ or NK-mediated lysis. ${ }^{33,66}$ Now we have found that a specific T-cell subset (ie, IRS ${ }^{+}$T cells obtained from patients with PNH) shows NK-like cytolytic activity to which $\mathrm{GPI}^{+} \mathrm{K} 562$ cells are more sensitive than $\mathrm{GPI}^{-} \mathrm{K} 562$ cells. If this difference applies
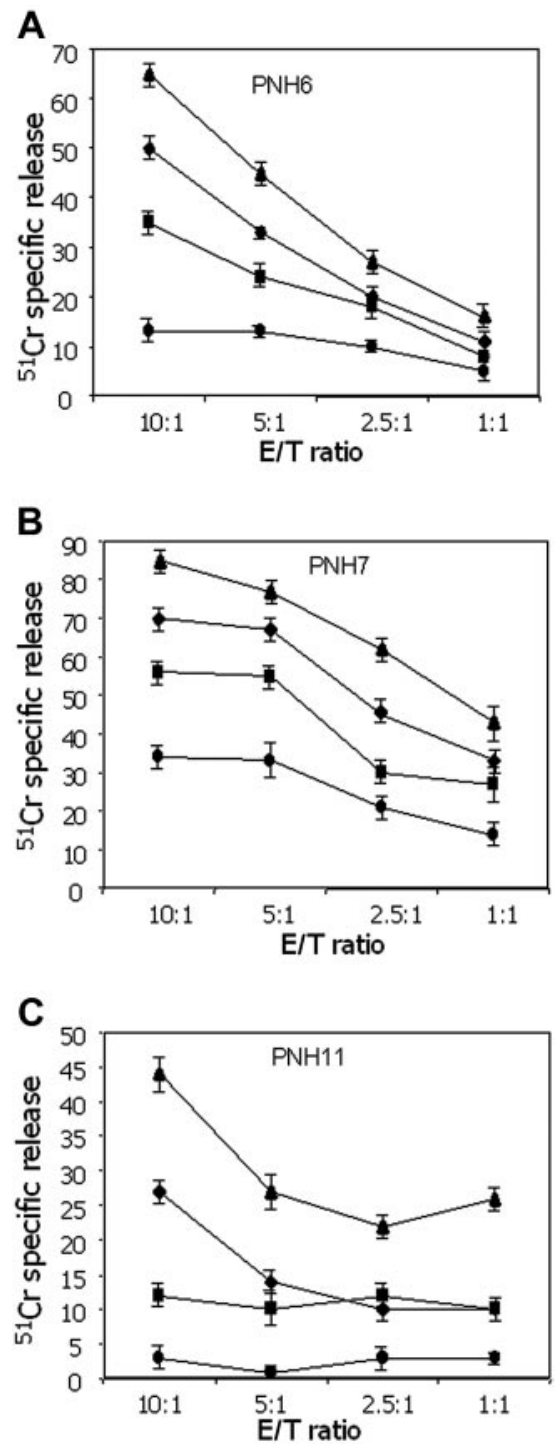

Figure 6. IRS ${ }^{+} \mathrm{T}$ cells from patients with $\mathrm{PNH}$ kill more efficiently $\mathrm{GPI}^{+}$than $\mathrm{GPI}^{-}$cells. Cytolytic activity of IRS ${ }^{+} \mathrm{T}$ cells from 3 different patients with $\mathrm{PNH}(\mathrm{A}$ : $\mathrm{PNH6}$; B: PNH7; C: $\mathrm{PNH} 11$ ) against $\mathrm{GPI}^{+} \mathrm{K} 562$ cell line or its $\mathrm{GPI}^{-}$counterpart (KCRN) was analyzed in a 4 -hour ${ }^{51} \mathrm{Cr}$ release assay at the indicated effector-target $(\mathrm{E} / \mathrm{T})$ ratios. Anti-LFA-1 $\mathrm{mAb}(5 \mu \mathrm{g} / \mathrm{mL})$ was added to the cytotoxic assay in order to block the contribution of LFA-1/ICAM-1 interaction to the activation of T cells. As the 2 K562 cell lines differ from each other for the expression of GPI-linked molecules, this shows the relative contribution of GPI molecules to target-cell lysis. Results are expressed as $\%$ of ${ }^{51} \mathrm{Cr}$ release, mean of triplicate samples plus or minus SD. indicates KCRN (K562 GPI); $\bullet$, KCRN (K562 GPI ${ }^{-}$) plus anti-LFA-1 mAb; $\mathbf{\Delta}, \mathrm{K} 562$ $\left(\mathrm{GPI}^{+}\right) ; \mathbf{\square}, \mathrm{K} 562\left(\mathrm{GPI}^{+}\right)$plus anti-LFA-1 mAb. 
to HSCs as well, this is one plausible mechanism whereby GPI deficiency would constitute a selective advantage for $\mathrm{GPI}^{-} \mathrm{HSCs}$, explaining the expansion of PNH hematopoiesis in the context of the bone marrow failure present in patients with $\mathrm{PNH}$. This bone marrow failure might be determined also by IFN- $\gamma$ and TNF- $\alpha$, cytokines that suppress hematopoiesis, ${ }^{40-44}$ produced by IRS $^{+}$ T-cell clones. Thus, the IRS ${ }^{+} \mathrm{T}$ cells we have characterized are good candidates for being able to damage $\mathrm{GPI}^{+} \mathrm{HSCs}$ in PNH.

\section{Acknowledgments}

We thank Robert Finberg (Boston, MA) for providing the $\mathrm{GPI}^{+}$and $\mathrm{GPI}^{-}$K562 cell lines and David Sanitzer (Duarte, CA) for providing the primers for KIR genotyping. We are grateful to Ji-Yao Sun (Duarte, CA) for the helpful technical suggestion for KIR genotyping and Martina Serra for help in the Laboratory of Human Genetics (LST, Genoa).

\section{References}

1. Oni SB, Osunkoya BO, Luzzatto L. Paroxysmal nocturnal hemoglobinuria: evidence for monoclonal origin of abnormal red cells. Blood. 1970;36: 145-152.

2. Takeda J, Miyata T, Kawagoe K, lida Y, et al. Deficiency of the GPI anchor caused by a somatic mutation of the PIG-A gene in paroxysmal nocturnal hemoglobinuria. Cell. 1993;73:703-711.

3. Bessler M, Mason PJ, Hillmen P, Miyata et al. Paroxysmal nocturnal haemoglobinuria $(\mathrm{PNH})$ is caused by somatic mutations in the PIG-A gene. EMBO J. 1994;13:110-117.

4. van der Schoot CE, Huizinga TW, van 't VeerKorthof ET, Wijmans R, Pinkster J, von dem Borne AE. Deficiency of glycosyl-phosphatidylinositol-linked membrane glycoproteins of leukocytes in paroxysmal nocturnal hemoglobinuria, description of a new diagnostic cytofluorometric assay. Blood 1990;76:1853-1859.

5. Bessler M, Schaefer A, Keller P. Paroxysmal nocturnal haemoglobinuria: insight from recent advances in molecular biology. Transfus Med Rev. 2001;15:255-267.

6. Dacie JV, Lewis SM. Paroxysmal nocturnal haemoglobinuria: clinical manifestations, haematology, and nature of the disease. Series Haematologica. 1972;5:3-23.

7. Young NS, Maciejewski JP, Sloand E, et al. The relationship of aplastic anemia and $\mathrm{PNH}$. Int J Hematol. 2002;76(suppl 2):168-172.

8. Young NS, Maciejewski J. The pathophysiology of acquired aplastic anemia. N Engl J Med. 1997; 336:1365-1372.

9. Karadimitris A, Manavalan JS, Thaler HT, et al. Abnormal T-cell repertoire is consistent with immune process underlying the pathogenesis of paroxysmal nocturnal hemoglobinuria. Blood. 2000;96:2613-2620.

10. Risitano AM, Kook H, Zeng W, et al. Oligoclonal and polyclonal CD4 and CD8 lymphocytes in aplastic anemia and paroxysmal nocturnal hemoglobinuria measured by $\mathrm{V}$ beta CDR3 spectratyping and flow cytometry. Blood. 2002;100:178-183.

11. Zeng W, Nakao S, Takamatsu H, et al. Characterization of T-cell repertoire of the bone marrow in immune-mediated aplastic anemia: evidence for the involvement of antigen-driven T-cell response in cyclosporine-dependent aplastic anemia. Blood. 1999;93:3008-3016.

12. Rotoli B, Luzzatto L. Paroxysmal nocturnal hemoglobinuria. Semin Hematol. 1989;26:201-207.

13. Luzzatto L, Bessler M, Rotoli B. Somatic mutations in paroxysmal nocturnal hemoglobinuria: a blessing in disguise? Cell. 1997;88:1-4.

14. Young NS, Maciejewski JP. Genetic and environmental effects in paroxysmal nocturnal hemoglobinuria: this little PIG-A goes "Why? Why? Why?." J Clin Invest. 2000;106:637-641.

15. Moretta A, Bottino C, Vitale M, et al. Receptors for HLA-class I molecules in human natural killer cells. Annu Rev Immunol. 1996;14:619-648.

16. Lanier LL. NK cell receptors. Annu Rev Immunol. 1998;16:359-393.

17. Long EO. Regulation of immune responses through inhibitory receptors. Annu Rev Immunol. 1999;17:875-904.

18. Cantoni $\mathrm{C}$, Biassoni R, Pende D, et al. The activating form of CD94 receptor complex: CD94 covalently associates with the Kp39 protein that represents the product of the NKG2-C gene. Eur J Immunol. 1998;28:327-338.

19. Perez-Villar JJ, Melero I, Rodriguez A, et al. Functional ambivalence of the Kp43 (CD94) NK cell-associated surface antigen. J Immunol. 1995 154:5779-5788.

20. Warren H, Campbell AJ, Waldron JC, Lanier LL. Biphasic response of NK cells expressing both activating and inhibitory killer Igh-like receptors. Int Immunol. 2001;13:1043-1052.

21. Poggi A, Tomasello E, Revello V, et al. p40 regulates NK cell activation mediated by NK receptors for HLA class I antigens and TCR-mediated triggering of T lymphocytes. Int Immunol. 1997;9: 1271-1279.

22. Mandelboim O, Kent S, Davis DM, et al. Natural killer activating receptors trigger interferon gamma secretion from T cells and natural killer cells. Proc Natl Acad Sci U S A. 1998;95:3798-3803.

23. Mandelboim O, Davis DM, Reyburn HT, et al. En hancement of class-II-restricted $\mathrm{T}$ cell responses by costimulatory NK receptors for class I MHC proteins. Science. 1996;274:2097-2100.

24. Namekawa T, Snyder MR, Yen J-H, et al. Killer cell activating receptor function as costimulatory molecules on $\mathrm{CD} 4{ }^{+} \mathrm{CD} 28^{\text {null }} \mathrm{T}$ cells clonally expanded in rheumatoid arthritis. J Immunol. 2000; 165:1138-1145.

25. Bertone S, Schiavetti F, Bellomo R, et al. Transforming growth factor-beta-induced expression of CD94/NKG2A inhibitory receptors in human T lymphocytes.Eur J Immunol. 1999;29:23-29.

26. D'Andrea A, Chang C, Phillips JH, Lanier LL. Regulation of $T$ cell lymphokine production by killer cell inhibitory receptor recognition of self HLA class I alleles. J Exp Med. 1996;184:789794

27. Young NT, Uhrberg M. KIR expression shapes cytotoxic repertoires: a developmental program of survival. Trends Immunol. 2002;23:71-75.

28. Poggi A, Pella N, Morelli L, et al. p40, a novel surface molecule involved in the regulation of the non-major histocompatibility complex-restricted cytolytic activity in humans. Eur J Immunol. 1995; 25:369-376.

29. Moretta A, Poggi A, Pende D, et al. CD69-mediated pathway of lymphocyte activation: anti-CD69 monoclonal antibodies trigger the cytolytic activity of different lymphoid effector cells with the exception of cytolytic T lymphocytes expressing T cell receptor $\alpha / \beta$. J Exp Med. 1991;174:1393-1398.

30. Spaggiari GM, Contini P, Carosio R, et al. Soluble HLA class I molecules induce natural killer cell apoptosis through the engagement of CD8: evidence for a negative regulation exerted by CD94/ NKG2A complex and KIR2D. Blood. 2002;99: 1706-1714.

31. Taswell C. Limiting dilution assay for the determination of immunocompetent cell frequencies, I: data analysis. J Immunol. 1981;126:1614-1619.
32. Zocchi MR, Rubartelli A, Morgavi P, Poggi A HIV-1 Tat inhibits human natural killer cell function by blocking L-type calcium channels. J Immunol. 1998;161:2938-2943.

33. Finberg RW, White W, Nicholson-Weller A. Decay-accelerating factor expression on either effector or target cells inhibits cytotoxicity by human natural killer cells. J Immunol. 1992;149:2055 2060.

34. Sun YJ, Gaidulis L, Miller MM, et al. Development of a multiplex PCR-SSP method for killer-cell immunoglobulin-like receptor genotyping. Tissue Antigens. 2004;64:462-468.

35. Hiby SE, Walker JJ, O'Shaughnessy KM, et al. Combinations of maternal KIR and fetal HLA-C genes influence the risk of preeclampsia and reproductive success. J Exp Med. 2004;200:957965.

36. Lamy T, Loughran TP Jr. Current concepts: large granular lymphocyte leukemia. Blood Rev. 1999; 13:230-240.

37. Rose MG, Berliner N. T-cell large granular lymphocyte leukemia and related disorders. Oncologist. 2004;9:247-258.

38. Karadimitris A, Li K, Notaro R, et al. Association of clonal T-cell large granular lymphocyte disease and paroxysmal nocturnal haemoglobinuria (PNH): further evidence for a pathogenetic link between $\mathrm{T}$ cells, aplastic anaemia and $\mathrm{PNH}$. $\mathrm{Br} \mathrm{J}$ Haematol. 2001;115:1010-1014.

39. Spaggiari $\mathrm{GM}$, Contini $\mathrm{P}$, Dondero $\mathrm{A}$, et al. Soluble HLA class I induces NK cell apoptosis upon the engagement of killer-activating HLA class I receptors through FasL-Fas interaction. Blood. 2002;100:4098-4107.

40. Zoumbos NC, Gascon P, Djeu JY, Young NS. Interferon is a mediator of hematopoietic suppression in aplastic anemia in vitro and possibly in vivo. Proc Natl Acad Sci U S A. 1985;82:188-192.

41. Miura A, Endo K, Sugawara T, et al. T cell-mediated inhibition of erythropoiesis in aplastic anaemia: the possible role of IFN-gamma and TNFalpha. Br J Haematol. 1991;78:442-449.

42. Maciejewski JP, Weichold FF, Young NS. HIV-1 suppression of hematopoiesis in vitro mediated by envelope glycoprotein and TNF-alpha. J Immunol. 1994;153:4303-4310.

43. Selleri C, Maciejewski JP, Sato T, Young NS. Interferon-gamma constitutively expressed in the stromal microenvironment of human marrow cultures mediates potent hematopoietic inhibition. Blood. 1996;87:4149-4157.

44. Binder D, van den Broek MF, Kagi D, et al. Aplastic anemia rescued by exhaustion of cytokinesecreting $\mathrm{CD}^{+}{ }^{+} \mathrm{T}$ cells in persistent infection with lymphocytic choriomeningitis virus. J Exp Med. 1998;187:1903-1920.

45. Katz G, Markel G, Mizrahi S, Arnon TI, Mandelboim O. Recognition of HLA-Cw4 but not HLACw6 by the NK cell receptor killer cell Ig-like receptor two-domain short tail number 4 . J Immunol. 2001;166:7260-7267.

46. Katz G, Gazit R, Arnon TI, et al. MHC class Iindependent recognition of NK-activating receptor KIR2DS4. J Immunol. 2004;173:1819-1825. 
47. Hillmen P, Lewis SM, Bessler M, Luzzatto L, Dacie JV. Natural history of paroxysmal nocturnal hemoglobinuria. N Engl J Med. 1995;333:12531258.

48. Alfinito F, Del Vecchio L, Rocco S, Boccuni P Musto P, Rotoli B. Blood cell flow cytometry in paroxysmal nocturnal hemoglobinuria: a tool for measuring the extent of the PNH clone. Leukemia. 1996;10:1326-1330

49. Rosti V, Tremml G, Soares V, Pandolfi PP, Luzzatto L, Bessler M. Murine embryonic stem cells without pig-a gene activity are competent for hematopoiesis with the $\mathrm{PNH}$ phenotype but not for clonal expansion. J Clin Invest. 1997;100:1028-1036.

50. Maciejewski JP, Sloand EM, Sato T, Anderson S Young NS. Impaired hematopoiesis in paroxysmal nocturnal hemoglobinuria/aplastic anemia is not associated with a selective proliferative defect in the glycosylphosphatidylinositol-anchored protein-deficient clone. Blood. 1997;89:1173-1181.

51. Murakami Y, Kinoshita T, Maeda Y, Nakano T, Kosaka H, Takeda J. Different roles of glycosylphosphatidylinositol in various hematopoietic cells as revealed by a mouse model of paroxysmal nocturnal hemoglobinuria. Blood. 1999;94:2963-2970.

52. Araten DJ, Nafa K, Pakdeesuwan K, Luzzatto L. Clonal populations of hematopoietic cells with paroxysmal nocturnal hemoglobinuria genotype and phenotype are present in normal individuals. Proc Natl Acad Sci U S A. 1999;96:5209-5214.

53. Barber DF, Faure M, Long EO. LFA-1 contributes an early signal for NK cell cytotoxicity. J Immunol. 2004;173:3653-3659.

54. Takagi J, Springer TA. Integrin activation and structural rearrangement. Immunol Rev. 2002; 186:141-163

55. Poggi A, Pardi R, Pella N, et al. CD45-mediated regulation of LFA1 function in human natural kille cells: anti-CD45 monoclonal antibodies inhibit the calcium mobilization induced via LFA1 molecules. Eur J Immunol. 1993;23:2454-2463.

56. Holguin MH, Fredrick LR, Bernshaw NJ, Wilcox $\mathrm{LA}$, Parker CJ. Isolation and characterization of a membrane protein from normal human erythrocytes that inhibits reactive lysis of the erythrocytes of paroxysmal nocturnal hemoglobinuria. J Clin Invest. 1989;84:7-17.

57. Rosse WF, Dacie JV. Immune lysis of normal human and paroxysmal nocturnal hemoglobinuria (PNH) red blood cells, I: the sensitivity of $\mathrm{PNH}$ red cells to lysis by complement and specific antibody. J Clin Invest. 1966;45:736-748.

58. Shichishima T, Saitoh Y, Terasawa T, Noji H, Kai T, Maruyama Y. Complement sensitivity of erythrocytes in a patient with inherited complete deficiency of CD59 or with the Inab phenotype. Br J Haematol. 1999;104:303-306.

59. Karadimitris A, Luzzatto L. The cellular pathogenesis of paroxysmal nocturnal haemoglobinuria. Leukemia. 2001;15:1148-1152.

60. Handgretinger R, Geiselhart A, Moris A, et al. Pure red-cell aplasia associated with clonal expansion of granular lymphocytes expressing killer-cell inhibitory receptors. $\mathrm{N}$ Engl J Med. 1999;340:278-284.

61. Schubert J, Uciechowski P, Delany P, Tischler HJ, Kolanus W, Schmidt RE. The PIG-anchoring defect in NK lymphocytes of PNH patients. Blood. 1990;76:1181-1187.

62. Tseng JE, Hall SE, Howard TA, Ware RE. Phenotypic and functional analysis of lymphocytes in paroxysmal nocturnal hemoglobinuria. Am J Hematol. 1995;50:244-253

63. Dacie JV. Paroxysmal nocturnal haemoglobinuria. In: Dacie JV, ed. The Haemolytic Anaemias: Drug and Chemical Induced Haemolytic Anaemias, Paroxysmal Nocturnal Haemglobinuria, and Haemolytic Disease of the Newborn. Vol 5. 3rd ed. London, United Kingdom: Churchill Livingston; 1999:139-330.

64. Luzzatto L, Notaro R. Paroxysmal nocturnal haemoglobinuria. In: Handin RI, Lux SE, Stossel TP, eds. Blood, Principles and Practice of Hematology. 2nd ed. Philadelphia, PA: Lippincott Williams \& Wilkins; 2003:319-334

65. Hollander N, Shin ML, Rosse WE, Springer TA. Distinct restriction of complement- and cellmediated lysis. J Immunol. 1988;142:3913-3916.

66. Karadimitris A, Notaro R, Koehne G, Roberts IAG, Luzzatto L. PNH cells are sensitive to T-cell mediated lysis as their normal counterparts: implication for the pathogenesis of paroxysmal nocturnal haemoglobinuria. Br J Haematol. 2000;111: 1158-1163. 